\title{
PARTISIPASI POLITIK PEREMPUAN (Studi tentang Relasi Kuasa dan Akses Perempuan dalam Pembangunan Desa di Desa Watoone - Kabupaten Flores Timur)
}

Frans Bapa Tokan1, Apolonaris Gai² dan Yohanes Negong ${ }^{3}$

1,2,3Program Studi Ilmu Pemerintahan, Universitas Katolik Widya Mandira, Kupang, Indonesia

\begin{abstract}
Abstrak
Proses pembangunan desa secara partisipatif dan berkelanjutan, mestinya mengikutsertakan secara aktif perempuan agar kepentingan esensialnya dapat terwujud dalam perencanaan dan penganggaran desa yang responsive gender dan gender budgeting. Secara kuantitatif kesadaran perempuan dalam mendukung pembangunan desa cukup tinggi. Namun secara kualitatif perempuan desa kurang mampu dan berani menyampaikan gagasan dan kritik dalam forum musyawarah desa. Relasi kuasa dan akses perempuan atas sumber daya desa masih terbatas karena kuatnya rezim oligarki desa berwajah otoritarian. Hadirnya relasi kuasa otoritarian juga dilanggengkan oleh kultur dan rendahnya tingkat pendidikan dan pengalaman perempuan desa. Dengan demikian penguatan kapasitas perempuan secara individu maupun kelompok melalui peningkatan pendidikan dan ketrampilan di berbagai bidang merupakan hal niscaya.
\end{abstract}

Kata Kunci: Partisipasi, Politik, Perempuan desa

\begin{abstract}
A participatory and sustainable village development process should actively involve women so that their essential interests can be realized in gender responsive village planning and budgeting and gender budgeting. Consciously, women and girls in supporting village development are quite high. However, qualitatively, village women are less capable and brave enough to convey ideas and criticism in village deliberation forums. The power relations and women's access to village resources are still limited due to the strong authoritarian-faced village oligarchy regime. The presence of authoritarian power relations is also perpetuated by the culture and low levels of education and the experiences of village women. Thus strengthening the capacity of individuals or groups to improve education and skills in various fields is a necessity.
\end{abstract}

Keywords: Participation, Politics, Village women

\section{PENDAHULUAN}

Pengelolaan pembangunan desa menuju kemandirian merupakan hakikat dari cita-cita perjuangan bangsa dan Visi UU Nomor 6 Tahun 2014 tentang Desa. Dalam ketentuan pasal 80 dan pasal 82, disebutkan bahwa 
proses perencanaan dan penganggaran desa harus melibatkan seluruh lapisan masyarakat desa dengan semangat gotong royong serta dijamin haknya dalam memantau dan mengontrol jalannya pembangunan.

Penegasan UU No.6 Tahun 2014 tentang Desa bertujuan memberi basis legitimasi pada proses pengambilan keputusan desa berdasarkan sistem perencanaan anggaran partisipatif dan responsive gender sehingga menghindari bias gender budgeting yang dapat merugikan kelompok perempuan miskin dan anak-anak. Karena itu menurut Venny (2006:5) anggaran berbasis gender tidak harus memiliki anggaran khusus di bidang pemberdayaan perempuan, namun sudah terintegrasi dalam keseluruhan jenis anggaran melalui alat analisa gender budgeting maupun audit gender.

Dalam terminologi partisipasi, pemilik dari sebuah sistem yang sedang berjalan adalah masyarakat itu sendiri sehingga tak heran apabila partisipasi sering dinaikkan maknanya menjadi emansipasi (Chambers, 1996; Cohen dan Uphoff, 1977), sehingga masyarakat harus dilihat sebagai subyek yang aktif dan diberi tempat istimewa dalam seluruh tahapan pembangunan. Menurut Cohen dan Uphoff,) ada beberapa tahapan dalam memahami partisipasi, yaitu partisipasi dalam perencanaan, pelaksanaan, pemanfaatan hasil dan partisipasi dalam tahap evaluasi, (Soetomo (2008:12). Dengan demikian untuk mewujudkan partisipasi aktif, perempuan mestinya selalu dilibatkan sejak dari awal proses perencanaan sampai dengan tahap evaluasi. Pelibatan perempuan sejatinya telah diatur secara khusus dalam Permendagri No.144 Tahun 2014 pasal 40 ayat (3) yang menyatakan dalam menyusun pelaksanaan kegiatan desa harus mengikut sertakan perempuan.

Menurut Venny, (2006:5) dalam praktek tata pemerintahan, pemerintah supra desa dan kepala desa sudah merasa cukup bila telah mengalokasikan sejumlah anggaran untuk kegiatan Dharma Wanita, PKK atau Majlis Ta'lim. Pada hal menurut Irlang, (2006:92) persoalan perempuan sangatlah kompleks ketika dikaitkan dengan ketidakadilan gender dalam masyarakat, terutama alokasi anggaran tanggap gender, semisal program 
pemberian beasiswa pendidikan dan kesehatan bagi anak laki-laki dan perempuan dari keluarga kurang mampu belum dilihat sebagai hal urgen.

Desa Watoone sebagai bagian dari wilayah Kabupaten Flores Timur dipilih menjadi sasaran kajian, karena secara umum dinilai cukup sukses dalam menata pembangunan desanya. Namun di sisi lain kurang sensitif terhadap isu gender sehingga menimbulkan kesenjangan dalam prencanaan anggaran dana desa di bidang pemberdayaan perempuan. Hal itu terbukti dari total APBDes Tahun 2019 sebesar Rp 1.025.581.281, dimana bidang pemberdayaan hanya dialokasikan anggaran sebesar Rp.22.495.000 dan dari jumlah ini sub bidang pemberdayaan perempuan, perlindungan anak dan keluarga mendapat bantuan sebesar Rp 6.240.000, (Kantor Desa, 2019). Akibatnya kepentingan perempuan dan anak-anak desa makin terabaikan dan ketimpangan pembangunan gender di semua aspek tak terhindarkan.

Data di depan memperlihatkan dengan sangat jelas bahwa prioritas pembangunan bidang pemberdayaan masyarakat pada umumnya dan khususnya perempuan belum menjadi perhatian utama pemerintah desa. Minimnya alokasi anggaran bagi perempuan diduga kuat karena lemahnya relasi kuasa dan akses dalam seluruh proses pembangunan di desa sejak dari awal perencanaan dan evaluasi.

Berdasarkan PermenDes Nomor 22 Tahun 2016 mengenai tata cara penggunaan dana desa diarahkan pada pelaksanaan pembangunan dan pemberdayaan masyarakat. Kemudian dipertegas dengan Permendagri Nomor 113 Tahun 2014 yakni 70\% untuk pelaksanaan pembangunan dan pemberdayaan serta $30 \%$ untuk penyelenggaraan pemerintahan dan pembinaan kemasyarakatan.

Mencermati data APBDes Tahun 2019 dan rujukan regulasi, mestinya porsi alokasi anggaran untuk kepentingan perempuan jauh lebih besar lagi. Ketimpangan anggaran desa yang cukup signifikan di bidang pembangunan dan pemberdayaan seharusnya tidak perlu terjadi, apabila semua pihak yang terkait dalam proses perencanaan pembangunan desa memiliki kepedulian terhadap kebutuhan esensial perempuan dan melibatkannya sejak dini. 
Studi ini sangat urgen bagi pengembangan ilmu pemerintahan terutama guna memahami makna pelibatan elemen masyarakat atas akses sumberdaya desa melalui suatu proses pengelolaan pembangunan desa yang partisipatif, berkelanjutan, transparan dan akuntabel.

\section{TINJAUAN PUSTAKA}

\section{Memahami Makna Partisipasi}

Partisipasi berasal dari kata bahasa Latin "partisipare" atau dalam bahasa Inggris "participation" yang artinya mengambil bagian atau turut serta. Menurut Sastropoetra, (1998) proses partisipasi digambarkan sebagai keterlibatan personal dalam bentuk: (1) ikut serta dalam proses pengambilan keputusan; (2) menentukan kebutuhan yang diinginkan; (3) menunjukkan dan mewujudkan tujuan dan prioritas yang ingin dicapai.

Dalam kaitan dengan hal ini maka partisipasi dapat dirumuskan sebagai suatu proses melibatkan diri secara sadar dari tiap individu maupun kelompok, langsung atau tidak langsung ikut dalam proses pengambilan keputusan dan bertanggungjawab terhadap pelaksanaan dan pemanfaatan hasil-hasilnya. Sedangkan Keith Davis,(1990) dalam karya berjudul "Human Relational Work"mengatakan "participationis defined as mental and emotional involment of a personin agroup situation which ecour ages him to contribute to group goals and share resposibility in them". Sedangkan Danil, (2006:6) memahami makna partisipasi sebagai sebuah peristiwa alami, tetapi melalui proses pembelajaran sosialisasi.

Berbeda dengan pandangan Danil dan lainnya, konsep Habermas dalam Rohman, dkk, (2009:33) tentang demokrasi deliberatif, memahami partisipasi masyarakat sebagai nyawa dari perencanaan pembangunan dan telah menjadi diskursus moral yang bisa diuji kesahihannya di ruang publik dan rasional. Itu sebabnya dalam proses musyawarah pembangunan, kata mufakat yang dicapai oleh para pihak selalu diwarnai oleh adanya dialog, diskusi dan debat alot di ruang publik sebagai suatu hal tak terhindarkan. 
Berkaitan dengan hal itu, Syahdan (2005:192-196) mengingatkan perlunya berhati-hati terhadap partisipasi, menurutnya ada beberapa hal yang mesti dicermati tentang pemaknaanya, yakni: (1) partisipasi bukan mobilisasi. Partisipasi sering dianggap sebagai kehadiran publik secara massal atau menggerakkan orang untuk berkumpul dan melakukan sesuatu; (2) partisipasi tidak berhenti pada kerangka keterwakilan formal. Ruang partisipasi seharusnya diperluas sampai batas terluar dari batas kekuasaan komunikatif yakni suara-suara bawah, media massa dan berbagai aspirasi dan opini publik di forum-forum warga; (3) partisipasi sebagai "agama baru". Paradigma partisipatif pada hakikatnya menggeser bandul orientasi perbincangan tentang pembangunan dari Negara dan pasar kepada masyarakat sipil. (4) partisipasi bukan hanya vote tetapi juga voice. Partisipasi bukan hanya masalah keterlibatan memberikan vote semata tetapi juga pada voice yang kemudian didiskusikan secara berkualitas di ruang publik.

\section{Partisipasi Masyarakat dalam Pembangunan}

Gagasan demokrasi deliberatif Habermas atau dalam perspektif demokrasi pancasila disebut konsep permusyawaratan, sebenarnya bukan merupakan hal baru bagi masyarakat desa. Menurut Rohman, dkk (2009:15) konsep deliberatif ditandai dengan adanya forum-forum publik yang digunakan membahas persoalan masyarakat yang secara empirik sudah lama dipraktekkan di Indonesia, seperti di daerah pedesaan dengan istilah rembug desa di pulau Jawa, tradisi gemohing dan pe'e put di pulau Adonara, Solor dan Lembata. Partisipasi dalam pembangunan desa juga bukan merupakan hal baru dalam masyarakat yang memiliki tradisi gotong royong dan swadaya.

Menurut Habermas, konsensus yang diraih dengan cara pemaksaan dan manipulasi tidak akan bermakna apa-apa selain keuntungan sepihak yang dinikmati oleh pihak yang kepentingannya tersalur melalui konsensus instan tersebut, (Hardiman, 2009:35). Sementara itu Arnstein dalam Rohman, ed (2009:47) membuat skema tingkatan partisipasi masyarakat dalam 
pembangunan, beberapa di antara adalah: (1) citizen control atau kontrol warga, pada tataran ini warga berwenang memutuskan, melaksanakan dan mengawasi pengelolaan sumber daya, inilah tahap tertinggi dari skema partisipasi Arnstein; (2)delegated power, dalam arti kewenangan warga lebih tinggi dari penyelengara Negara dalam proses pengambilan keputusan, karena itu warga harus didengar dan diikutsertakan dalam proses pengambilan keputusan; (3)partnership atau kemitraan, pada tahap ini harus ada keseimbangan kekuatan relatif antara masyarakat dan pemegang kekuasaan untuk merencanakan dan mengambil keputusan bersama-sama. Pandangan Arnstein dimuka memperlihatkanadanya peluang yang makinterbuka dan luasuntuk berpartisipasi di era demokrasi yang berbasis pada kuasa rakyat.

\section{Beberapa faktor penghambat partisipasi dalam pembangunan}

Dalam praktek berdemokrasi, partisipasi seringkali dihambat oleh sejumlah faktor baik di lingkungan internal maupun eksternal. Menurut Sumarto, (2009:20) ada tiga faktor yang selama ini menjadi faktor penghambat partisipasi, yakni: (1) hambatan struktural, hambatan ini berkaitan dengan struktur politik yang meliputi konstitusi dan birokrasi; (2) hambatan kultural, hambatan ini terjadi di level internal masyarakat sendiri, dimana gairah partisipasi yang kuat belum membudaya. Hal itu ditandai dengan kurangnya inisiatif warga untuk hadir dan terlibat secara aktif dalam proses pengambilan keputusan; (3) hambatan teknis, hambatan ini berhubungan dengan kurangnya pemahaman masyarakat tentang metode dan teknik-teknik berpartisipasi dalam pembangunan. Karena bahasa prosedur yang dipakai dalam perencanaan musrenbangdes adalah bahasa birokratis yang tidak semua orang memahaminya.

Tidak jauh berbeda dengan pandangan Sumarto, menurut Leo, (2007:231) yang lebih menyoroti sejumah kendala penghambat partisipasi perempuan, di antaranya: (1) kendala politik,yakni keberadaan model politik / institusi yang diformulasikan sekaligus didominasi kaum pria menyebabkan perempuan menolak budaya politik bergaya pria; (2) kendala ideologis; salah 
satu jargon ideologis yang mengekang aktivis perempuan ialah adanya ungkapan: "ketika perempuan menjadi politisi, ia berhenti manjadi (seorang) ibu"; (3) kendala sosio ekonomi, kondisi sosio-ekonomi memainkan peranany ang menentukan dalam rekruitmen anggota organisasis osial-politik baik dalam demokrasi yang baruberkembang maupun pada demokrasi yang sudah mapan.

Sedangkan menurut Fakih dalam Romli, (2014) ada beberapa hambatan perempuan dalam pembangunan desa, yakni: (1) Tradisi, sikap dan prasangka yang menolak partisipasi perempuan dalam kegiatan ekonomi, sosial dan politik; (2) hambatan-hambatan legal; (3) keterbatasan akses terhadap pendidikan formal,yang berdampak pada tingginya jumlah buta huruf pada perempuan; (4) beban kesehatan pada saat kehamilan, kekurangan makanan dan gizi. Hambatan-hambatan yang dialami perempuan dalam pembangunan kemudian menurut Fakih telah berdampak pada masalah ketidakadilan gender, yakni: (1) Kemiskinan ekonomi terhadap kaum perempuan; (2) Terjadinya subordinasi pada salah satu jenis sex, yang umumnya pada kaum perempuan; (3) Pelabelan negatif (stereotype) terhadap jenis kelamin tertentu,terutama terhadap kaum perempuan; (4) Kekerasan yang pada umumnya dialami oleh perempuan; (5) Karena peran gender perempuan adalah pengelola rumah tanggadan menanggung beban kerja domestik lebih banyak dan lebih lama.

Dengan demikian akar ketidakadilan gender yang dialami perempuan sampai saat ini berawal dari struktur dan kultur budaya patriarki yang terlalu lama membentuk alam pemikiran dan tindakan suatu masyarakat yang kemudian dianggap sebagai sebuah kebenaran kolektif. Atau dengan kata lain, lahirnya ketidakadilan gender karena adanya pelanggengan dosa struktural dan kultural dalam suatu masyarakat.

\section{Relasi Kuasa dan Akses Perempuan dalam Pembangunan Desa}

Akses perempuan dalam proses pembangunan desa dapat dipahami 
sebagai suatu kemampuan yang dimiliki oleh seseorang maupun kelompok perempuan mempengaruhi dan memperoleh kemudahan serta manfaat atas fasilitas publik dan kontrol sumberdaya pembangunan di desa, seperti program pembangunan bidang pendidikan dan pelatihan, kesehatan, permodalan maupun posisi serta pekerjaan lain di desa. Berkaitan dengan itu Amartya Sen dalam Claros dan Zahidi, (2005:2) mengatakan pendidikan, pekerjaan dan kepemilikan hak perempuan memberikan pengaruh kuat untuk meningkatkan kemampuan mereka menguasai lingkungannya dan memberikan kontribusi bagi pembangunan ekonomi. Partisipasi ekonomi tidak hanya berhenti pada meningkatnya jumlah perempuan bekerja, melainkan pula kesetaraan dalam pemberian upah. Menurut Kabeer, (2001) akses dapat diartikan sebagai kemampuan perempuan memperoleh hak atas sumberdaya produktif, seperti: tanah, kredit, pelatihan, fasilitas pemasaran, tenaga kerjadan semua pelayanan publik yang setara dengan laki-laki. Akses terhadap teknologi \& informasi juga merupakan aspek penting lain. Melalui teknologi informasi, perempuan dapat meningkatkan produktivitas ekonomi, sosial dan politik mereka dan mempengaruhi lingkungan tempat ia tinggal.

Sedangkan pola relasi kuasa yang demokratis akan berimplikasi pada adanya akses dan kontrol yang mudah atas sumber daya desa. Relasi dan akses dalam konteks ini adalah dua hal yang saling kait mengkait dan bersinergi dalam suatu jaringan organisasi untuk mempengaruhi proses pengambilan keputusan. Dalam Permendagri No.144 Tahun 2014 pasal 40 ayat (3) ditegaskan tentang keharusan melibatkan perwakilan perempuan dalam setiap proses pembangunan desa. Namun dalam tataran implementasi sering sulit terealisasi, terutama terkait kepentingan perempuan dan anakanak.

Ketidakseriusan Negara dan kendala budaya pada akhirnya melumpuhkan daya kritis dan kekuatan perempuan dalam sejumlah aktivitas di ruang publik dan kuasa itu sangat berhubungan erat dengan proses 
pengambilan keputusan. Ketika kuasa tubuh dan pengetahuan dilumpuhkan, maka apapun yang disuarakan akan menjadi tak bermakna.

Dalam kacamata Weber seperti dikutip Lukes, (1986) kekuasaan selalu dikaitkan dengan dominasi, yaitu situasi ketika keinginan dimanifestasikan dalam bentuk perintah dari orang yang berkuasa atau membuat peraturan untuk mempengaruhi tingkah laku orang yang dikuasai, sehingga terkadang perintah tersebut seolah-olah datang dari hati mereka sendiri. Sedangkan menurut Ruspita, (2012:26) dalam teori feminis, kekuasaan merupakan sebuah kerjasama dalam mencapai tujuan. Menurut Cantor dan Bernay dalam Ruspita (2012:26) kekuasaan dari perspektif feminis merupakan pengaturan sosial dalam masyarakat yang tidak bertentangan dengan maskulinitas dan feminitas.

Kekuasaan dalam hal ini setidaknya mengandung nilai-nilai pemberdayaan terhadap orang lain yang dipengaruhi dengan tujuan untuk menciptakan kondisi masyarakat yang lebih baik. Kekuasaan diperlukan untuk memahami bahwa dalam kehidupan material selalu terjadi penstrukturan hubungan sosial-material dimana semua pihak dipaksa berpartisipasi.

Mengkaji sumber kekuasaan dan material, Rosaldo (1974) memandang kekuasaan dan nilai dapat diperoleh perempuan dalam peran domestik dan publik. Karena itu kesempatan perempuan untuk memperoleh kekuasaan dapat dilakukan dengan memasuki wilayah laki-laki di ruang publik atau dengan menerima legitimasi fungsi domestik atau menciptakan dunia mereka sendiri melalui alokasi penghasilan perempuan terhadap ekonomi rumah tangga, mengumpulkan kekayaan melalui kontrol terhadap makanan dan membentuk kelompok tertentu dalam keluarga dan masyarakat.

Berkaitan dengan alokasi dan pembagian peran, Karl Marx seperti dikutip Suseno (1999), mengatakan pekerjaan sebagai sarana realisasi diri manusia seharusnya memberi kesenangan atau kegembiraan dan kepuasan, dengan pekerjaannya manusia dapat membuat dirinya menjadi nyata. Dalam 
praktek hidup sehari-hari perempuan desa masih dikonstruksi oleh budaya patriarki sebagai pekerja domestik tanpa upah sehingga walaupun sudah bekerja penuh waktu mati-matian di dalam rumah, namun masih tetap dianggap rendah karena tak bernilai ekonomi dalam masyarakat. Sedangkan laki-laki yang bekerja di sektor publik selalu dihargai dengan upah bernilai ekonomi yang dibutuhkan bagi kelangsungan hidup rumah tangga. Relasi kuasa perempuan yang timpang dalam kehidupan rumah kemudian terbawa masuk sampai ke luar rumah ketika perempuan berinteraksi dengan lakilaki di ruang publik.

Sejalan dengan pandangan Marx, Gramsci mencoba memahami relasi kuasa dari sisi hegemoni. Titik tolak konsep Gramsci tentang hegemoni adalah suatu kelas dan anggotanya menjalankan kekuasaan terhadap kelaskelas dibawahnya dengan cara kekerasan dan persuasi. Hegemoni menurut Gramsci, (Simon, 2004:21-23) bukanlah hubungan dominasi dengan memanfaatkan kekuasaan, melainkan hubungan persetujuan dengan menggunakan kepemimpinan politik dan ideologis. Karena itu menurut Gramsci, hegemoni memerlukan penyatuan berbagai kekuatan sosial yang berbeda kedalam suatu aliansi luas yang mengungkapkan kehendak kolektif semua rakyat, sehingga masing-masing kekuatan tersebut bisa mempertahankan otonominya sendiri dan memberikan sumbangan dalam gerakan menuju masyarakat yang berkeadilan sosial.

Sedangkan Foucault melihat konsep kekuasan dari sudut pandang yang berbeda dengan Marx, Weber dan Gramsci serta para ahli sebelumnya. Kekuasaan menurut Foucault dalam Mudhoffir (2013:77-79) tidak dipahami secara negatif seperti dalam perspektif Marxian melainkan produktif dan reproduktif. Ia tidak terpusat tetapi menyebar dan mengalir dinormalisasikan dalam praktek pendisiplinan. Disiplin merupakan bentuk normalisasi kekuasaan yang berlangsung dalam suatu institusi terhadap tubuh individu. Foucault melihat kekuasaan sebagai relasi-relasi yang beragam dan tersebar seperti jaringan yang mempunyai ruang lingkup strategis. Pandangan Foucault 
di depan memberi pesan kuat bahwa kekuasaan tidak lagi terpusat pada satu tangan melainkan sudah tersebar ke berbagai simpul masyarakat yang tentunya menuntut adanya dialog dan sinergitas ketika mengambil keputusan publik.

Pandangan berbeda dari Haryanto, dkk dalam Pratikno, ed ( 2007: 4953) bahwa pola relasi kuasa antara pemerintah dengan masyarakat dapat dibagi kedalam beberapa bagian, yakni: (1) pola otoritarian, pola ini menempatkan posisi pemerintah berada di tempat tertinggi sedangkan masyarakat berada dalam posisi subordinatif. Dalam pola hubungan ini hampir seluruh kelembagaan masyarakat dikooptasi, gerak gerik setiap warga diinteli oleh aparat keamanan dan birokrasi pemerintah. Fungsi birokrasi yang seharusnya menjadi pelayanan masyarakat berubah menjadi pelayan rezim. Sebaliknya masyarakat dikondisikan pada posisi pasif dan perannya nyaris terpinggirkan; (2) Pola hubungan transisional, pola hubungan ini ditandai dengan mencairnya dominasi pemerintah atas masyarakat. Pola ini kemudian diwarnai oleh ketegangan, konflik bahkan perlawanan dari masyarakat karena produk politik yang ada hanya menguntungkan pemerintah; (3) Pola hubungan demokratis, adalah suatu model hubungan yang menempatkan pemerintah dan masyarakat dalam posisi setara, karena pemerintah tidak dapat melakukan dominasi atas peran dan fungsinya dihadapan masyarakat.

Setiap perumusan kebijakan dan implementasis eharusnya melalui proses partisipasi secara luas dan menyeluruh di tingkat lapisan masyarakat. Pola relasi kuasa ini sesungguhnya hampir sejalan dengan apa yang digagas oleh Habermas tentang konsep demokrasi deliberatif yang menekankan proses pengambilan keputusan melalui sebuah proses pertukaran ide dan argumentasi dengan menyertakan partisipasi aktif seluruh lapisan masyarakat.

\section{METODE PENELITIAN}

Metode yang sesuai dengan penelitian ini adalah metode deskriptif analitik, dengan analisis menggunakan pendekatan kualitatif yakni data dan 
informasi yang dikumpulkan melalui amatan dinamika proses di lapangan berupa kata-kata, gambar, dan bukan angka-angka. Data kuantitatif hanya dibutuhkan untuk melengkapi kajian kualitatif. Karena itu data yang disajikan dalam laporan berasal dari observasi, naskah wawancara, catatan lapangan, foto, video tape, dokumen pribadi dan catatan resmi lain. Dengan demikian menurut Moleong, (2013:11) data yang dikumpulkan lebih terfokus pada katakata dan gambar yang diperoleh di lapangan.

\section{HASIL DAN PEMBAHASAN}

Secara faktual mayoritas jabatan penting di tingkat pemerintahan desa, seperti jabatan Kepala Desa, Sekretaris Desa, Kepala urusan dan Kepala Dusun semuanya diduduki laki-laki. Sedangkan perempuan hanya diberikan jabatan sisa sebagai ketua RT dan satu di antaranya adalah jabatan Kepala Urusan.

Mencermati komposisi jabatan publik desa menunjukkan bahwa proses pemilihan dan pengangkatan jabatan penting di desa, dalam proses pengambilan keputusannya cenderung bias gender dan terindikasi sarat dengan isu kedekatan keluarga. Namun ada sejumlah alasan pembenar yang dikemukakan oleh Kepala Desa berikut:

“ Untuk menduduki jabatan-jabatan publik di desa seperti kepala desa, Sekdes dan kepala dusun sudah berjalan sesuai peraturan dan prosedur demokrasi yang berlaku yaitu dipilih secara langsung oleh warga desa. Namun untuk kasus desa Watoone jabatan-jabatan lain seperti KAUR dan Ketua RT ketika ditawari hampir semua warga terutama laki-laki menolak dengan berbagai alasan, bahkan sejumlah warga ketika diundang rapatpun menolak hadir. Karena itu untuk mengisi kekosongan jabatan, saya lakukan dengan cara penunjukkan terhadap sejumlah orang tertentu yang bersedia menerima jabatan itu".

Sedangkan beberapa warga desa yang ditemui penulis mengungkapkan bahwa mereka menolak jabatan di desa karena takut terperangkap dalam konspirasi penggunaan dana desa yang cenderung dikelola secara tidak transparan dan akuntabel. Petikan wawancara di depan menunjukan bahwa 
alasan penolakan sejumlah laki-laki atas posisi Kaur dan Ketua RT di Desa Watoone, bukan karena mereka tidak tertarik dengan jabatan itu tetapi karena tidak ingin terjebak dalam persoalan hukum terkait pengelolaan dana desa. Karena itu sejumlah perempuan dan laki-laki yang menerima tawaran sebagai Kaur dan ketua RT adalah orang-orang yang mau mengabdi dan bisa diajak bekerjasama.

Perubahan penting yang ditemukan di lapangan adalah telah terjadi pergeseran pada sejumlah jabatan rendah di tingkat rukun tetangga (RT) dari 23 jabatan ketua RT di desa Watoone, 15 jabatan di antaranya dipegang oleh kaum perempuan atau sebesar (65\%) melalui proses musyawarah warga di tingkat RT dan sebagian lewat penunjukkan kepala desa. Itu berarti partisipasi perempuan dalam jabatan publik desa setingkat ketua RT dari sisi jumlah mulai mengalami perubahan signifikan karena sebelumnya didominasi laki-laki.

Dari perspektif demokrasi proses pemilihan ketua RT masih menyimpan masalah karena secara prosedural dan substantif tindakan penunjukkan yang dilakukan oleh kepala desa telah menodai nilai-nilai demokrasi yang mensyaratkan adanya kompetisi, pilihan bebas dan proses musyawarah di ruang publik.

Beberapa kalangan tokoh desa yang ditemui penulis menilai bahwa persoalan penolakan jabatan oleh sejumlah warga merupakan bentuk protes warga atas tata kelola pemerintahan dan pembangunan desa yang dinilai kurang transparan. Fenomena pemerintah desa yang kurang transparan telah menimbulkan spekulasi dan tanda tanya sekelompok warga mengenai dugaan adanya penyimpangan dana desa di internal pemerintah desa yang sengaja ditutupi.

Data empirik lain juga memperlihatkan bahwa komposisi keanggotaan dalam lembaga BPD dari sisi kuantitas sudah cukup memadai karena dari sembilan orang anggota $\mathrm{BPD}$, enam orang di antaranya laki-laki dan tiga lainnya perempuan. Keberadaan ketiga orang perempuan ini oleh banyak 
kalangan di desa juga dinilai hanya sekedar memenuhi persyaratan keterwakilan. Fenomena pelibatan perempuan sebagai anggota BPD di Desa Watoone setelah dicermati, ternyata bukan berlangsung atas dasar kesadaran tinggi perempuan akan pentingnya kedudukan BPD sebagai wakil masyarakat desa, melainkan hanya untuk memenuhi persyaratan administrasi belaka dan karenanya terkesan dimobilisasi guna memenuhi keterwakilan perempuan.

Dalam PP No 43 Tahun 2014 tentang Desa pasal 72 ayat (1) pengisian keanggotaan BPD dilaksanakan secara demokratis melalui proses pemilihan secara langsung atau musyawarah perwakilan dengan menjamin keterwakilan perempuan. Oleh karena itu partisipasi politik perempuan pada level BPD di Desa Watoone dalam perspektif demokrasi deliberatif ala Habermas dapat dikategorikan sebagai bentuk pemaksaan atau dimobilisasi. Karena proses pelibatan perempuan telah mengabaikan kebebasan dan kesadaran kritis perempuan. Partisipasi dengan cara demikian sejatinya tidak dianjurkan dalam proses rekrutmen anggota BPD yang merupakan wujud nyata dari wahana demokrasi desa.

Proses pemilihan anggota BPD yang mencoba menihilkan makna demokrasi dinilai sebagai tindakan yang anti demokrasi. Hal ini sebenarnya telah diingatkan oleh Syahdan, (2005) tentang kehati-hatian dalam memaknai partisipasi, yakni partisipasi tidak diartikan sebagai tindakan menggerakkan orang lain untuk berkumpul melalui cara memobilisasi serta partisipasi tidak berhenti pada kerangka keterwakilan formal dan prosedural semata. Partisipasi mestinya dibarengi dengan suatu kesadaran kritis ketika menerima jabatan publik karena secara politik seorang anggota BPD harus aktif dan bertanggung jawab menyampaikan suara-suara kritis dalam forum warga.

Temuan menarik lain mengkonfirmasi bahwa musyawarah di level RT tidak pernah dilakukan oleh para ketua RT di masing-masing Dusun, karena selama ini ketua RT hanya dipandang sebagai perpanjangan tangan dari pemerintah desa semata yang kerjanya hanya melayani pemerintah desa dan 
memberi persetujuan pada musrenbangdes. Selain itu para ketua RT juga bertugas menyampaikan informasi dari pemerintah desa mengenai kegiatan pembangunan fisik yang akan dikerjakan masyarakat, termasuk ikut membagi raskin kepada warga penerima raskin. Meskipun mayoritas perempuan kurang bersuara kritis di sejumlah forum warga seperti di tingkat RT, Dusun dan Desa, namun perempuan umumnya sangat bertanggung jawab atas pelaksanaan pembangunan desa. Hal itu terbukti dari tingginya pelibatan perempuan di sejumlah program pembangunan fisik desa, seperti pembukaan jalan desa, jalan tani dan pembangunan fisik lain.

Perempuan desapun telah berinisiatif membentuk wadah kerjasama di beberapa bidang, seperti tenun ikat dan jasa sewa fasilitas untuk kegiatan sosial di desa.Namun sejumlah perempuan mengakui bahwa selama ini mereka kurang mendapat perhatian serius dari pemerintah desa dalam penguatan kapasitas baik secara individu dan organisasi terutama terkait dukungan pengembangan modal dan ketrampilan.

Walaupun kelompok perempuan selalu terlibat aktif dalam pembangunan, namun kepentingannya sering terabaikan, bahkan perempuan selalu diakali dan dimanfaatkan tenaganya untuk menggolkan program pembangunan fisik desa. Sementara kepentingannya jarang diakomodasi dalam program pembangunan desa. Hal itu terbukti dari sejumlah program pembangunan desa yang tidak responsive gender.

Data APBDes di Desa Watoone Tahun 2019 sebesar Rp 1.025.581.281, dimana bidang pemberdayaan hanya dialokasikan anggaran sebesar Rp.22.495.000 dan dari jumlah ini sub bidang pemberdayaan perempuan, perlindungan anak dan keluarga mendapat bantuan sebesar Rp 6.240.000. Suatu jumlah yang sangat tidak layak untuk memberdayakan kelompok perempuan dan anak-anak.

Pada hakikatnya relasi kuasa masyarakat termasuk kelompok perempuan sudah dilembagakan dalam pasal $112 \mathrm{~s} / \mathrm{d}$ pasal 115 UU No. 6 Tahun 2014 tentang Desa. Di dalam UU tersebut diatur tentang pola pembinaan, pemberdayaan dan kontrol terhadap desa, agar tata kelola 
pemerintah desa dapat berlangsung secara demokratis dan menjangkau semua kepentingan warga desa termasuk kelompok perempuan dan anakanak. Relasi kuasa perempuan kemudian dipertegas lagi dalam Permendagri No.144 Tahun 2014 pasal 40 ayat (3) tentang keharusan melibatkan perwakilan perempuan dalam setiap proses pembangunan desa.

Dalam perspektif kekuasaan yang bersifat normatif, setidaknya ada pintu masuk bagi kelompok perempuan memainkan fungsi strategisnya mempengaruhi berbagai kebijakan dan program pembangunan desa. Karena secara nyata kekuasaan memang selalu bersifat menyebar dalam masyarakat dan bukan lagi terpusat pada satu tangan. Sebab masih ada tangan-tangan lain yang tersebar dan sedang ikut mengontrol dalam masyarakat yang perlu diperhitungkan oleh penguasa, salah satu di antaranya adalah perempuan.

Perempuan yang menjadi bagian dari entitas politik merupakan salah kekuatan sosial dan politik desa yang memiliki pengaruh tetapi selalu sulit diwujud nyatakan dalam ruang-ruang publik. Atau dengan kata lain kuasa perempuan memang ada namun terkendala oleh sistem pemerintahan desa berwatak patriarki-otoritarian yang justru menjadi penghalang utama ketika hendak merumuskan program-program yang berpihak pada perempuan.

Kesulitan yang dihadapi ketika hendak mendorong kuasa perempuan berperan pada ruang-ruang publik desa karena pemerintah desa juga terperangkap dalam budaya patriarki yang terwujud dalam kebijakan dan program yang bias gender. Hal itu terkonfirmasi dari sejumlah jabatan publik desa yang diberikan kepada perempuan, seperti menjadi anggota BPD, Kaur dan ketua RT, namun kemudian terkooptasi oleh kekuatan hegemoni kepala desa sehingga jabatan ini tak lebih dari alat untuk menormalkan kepatuhan perempuan dan melanggengkan kuasa laki-laki.

Mestinya kekuasaan yang ada pada diri perempuan selaku ketua RT, Kaur dan anggota BPD bisa dijadikan sebagai media dalam mengelola dan memperjuangkan hak-haknya yang selama ini terpinggirkan. Itu sebabnya relasi kuasa perempuan dibutuhkan lewat penyatuan kekuatan bersama 
dengan satu tujuan yang sama membangun relasi kuasa yang adil. Fakta membuktikan bahwa eksistensi perempuan dalam menduduki sejumlah jabatan publik desa hanyalah merupakan cek kosong dan formalisme belaka yang justru tak disadari sendiri oleh kelompok perempuan. Karena jabatanjabatan yang diemban tak dibarengi dengan tingkat pengetahuan dan pengalaman memadai sehingga tak memberi efek positif pada perbaikan kebijakan dan program yang lebih nyata untuk perempuan.

Data yang telah tersaji sebelumnya memberi pesan kuat bahwa akses kebijakan dan program bagi perempuan membutuhkan perjuangan yang tak mudah, bila tidak disertai dengan keberanian bersuara kritis di ruang publik. Sejatinya kehadiran perempuan di ruang publik saja tidak cukup kuat mengakses program yang dibutuhkan, karena harus disertai dengan keberanian dan kecerdasan bersuara menyampaikan gagasan kritis dan meyakinkan forum bahwa ide yang sedang diperjuangkan penting digolkan dalam program pembangunan desa.

Kelemahan paling mendasar yang dihadapi kaum perempuan desa pada umumnya adalah rendahnya tingkat pendidikan, ketrampilan dan pengalaman berorganisasi. Akibatnya perempuan gagal menyampaikan aspirasi dan gagasan kritis di forum desa kedalam agenda kebijakan dan program pembangunan desa yang lebih responsif gender.

\section{KESIMPULAN}

Partisipasi politik perempuan desa di Desa Watoone mulai mengalami kemajuan, tetapi secara substantif belum memberikan perubahan signifikan pada perbaikan kebijakan dan perencanaan anggaran bagi kepentingannya, antara lain:

1. Pelibatan perempuan desa dalam proses pembangunan fisik desa tidak bisa diragukan karena perempuan desa jauh lebih aktif dengan atau tanpa diupah, jika dibandingkan dengan kehadiran laki-laki. Walaupun secara kualitatif perempuan desa masih harus berjuang keras dan belajar banyak bagaimana mempengaruhi agenda kebijakan dan perencanaan anggaran desa 
agar lebih responsive gender melalui forum musyawarah desa dan musrenbangdes.

2. Relasi kuasa dan akses perempuan sejatinya secara normatif sudah diatur dalam berbagai regulasi tentang desa, tetapi dalam praktek masih saja terbentur oleh struktur dan kultur pemerintahan desa yang berwatak patriarki-otoritarian. Itu sebabnya relasi kuasa perempuan dengan rezim desa lebih bersifat dominatif yang berpusat pada figur kepala desa selaku representasi laki-laki.

Saran yang diberikan dalam penelitian ini adalah:

1. Kelompok perempuan secara kelembagaan dan individu perlu melakukan upaya penguatan kapasitas dirinya melalui proses pendidikan dan latihan ketrampilan serta memperluas wawasan, melalui pelibatannya dalam berbagai aktifitas sosial dan politik agar dapat bersuara kritis di forum musyawarah desa musrenbangdes.

2. Selain pendidikan vokasi, pendidikan formal perempuanpun mesti terus ditingkatkan lebih serius seiring dengan peningkatan kemampuan profesional di berbagai bidang profesi yang akan digeluti, agar kelak dapat mengisi ruang-ruang publik setara laki-laki.

\section{DAFTAR PUSTAKA}

Chambers, Robert, Pembangunan Masyarakat Desa, mulai dari belakang, LP3ES, Jakarta, 1996

Conyers, Diana, Perencanaan Sosial di Dunia Ketiga, Yogyakarta : Gajah Mada University Press, Yogyakarta, 2004

Cohen dan Uphoff, Rural Development Participation: Concept and Measures For Projec tDesign Implementation and Evaluation: Rural Development Commite- Cornel University, New York, 1977

Claros, Augusto Lopez dan Saadia Zahidi, 2005, Woman Empowerment:Measuring The Global Gender Gap.Worl Economic Forum. Diakses dari situs, www.weforum.org 
Danil, Moehar, dkk, PRA Participatory Rural Appraisal Pendekatan Efektif Mendukung Penerapan Penyuluhan Partisipatif dalam Upaya Percepatan Pembangunan Pertanian, Bumi Aksara, Jakarta, 2006

Davis, Keith, 1990, Perilaku dalam Organisasi; Jakarta: Erlangga

Fakih,Mansour, Analisis Gender dan TransformasiS osial, INSIST Press, Yogyakarta, 2008

Hardiman, F. Budi, Demokrasi deliberatif : Menimbang Negara Hukum dan Ruang Public dalam Teori Diskursus Jurgen Habermas, Kanisius, Yogyakarta, 2009

Leo, Agustino, Dasar-dasar kebijakan publik (edisi revisi), Alfabeta-Bandung, 2007

Lukes,S, Power, Oxford: Basil Blackwell ltd, 1986

Moleong, Lexy J., Metode Penelitian Kualitatif, Remaja, Jakarta, 2013

Pratikno, ed, Mengelola Dinamika Politik dan Jejaring Kepemerintahan Daerah: kemitraan, partisipasi dan pelayanan publik, Jogja Global Media, Yogyakarta, 2007

Rohman, Ainur, dkk, Politik, Partisipasi dan Demokrasi dalam Pembangunan, Adverroes Press, Malang, 2009

Rosaldo, Michile Z. And L.Lamphere, Women, Cultur and Society, Stanford University Press, California, 1974

Romli, Lili: Makalah, Pengakuan dan Penguatan Peran Perempuan dalam Implementasi UU Desa No 6 Tahun 2014 Tentang Desa, Kementerian Desa, Pembangunan Daerah Tertinggal dan Transmigrasi, 2014

Simon, Roger, Gagasan-gagasan Politik Gamsci, Pustaka pelajar, Yogyakarta, 2004

Syahdan, Gregorius (ed), Transformasi Ekonomi Politik Desa, Yogyakarta, AM PD Press, Yogyakarta, 2005

Shuida, I Nyoman, Buku Bantu Pengelolaan Pembangunan Desa, Deputi Koordinasi Pemberdayaan Masyarakat, Desa dan Kawasan Menko BPMK RI, Jakarta, 2016 
Sumarto, Hetifah Sj. ,Inovasi, Partisipasi dan Good Governance: 20 Prakarsa Inovatif dan Partisipasidi Indonesia, Obor , Jakarta, 2009

Soetomo, Strategi-strategi Pembangunan Masyarakat, Pustaka Pelajar, Yogyakarta, 2008

Suseno, Frans Magnis, Pemikiran Karl Marx, Gramedia Pustaka Utama, Jakarta, 1999

Sastropoetro, R.A.S, Partisipasi Komunikasi, Persuasi dan Disiplin dalam Pembangunan, Alumni, Bandung, 1998

\section{Jurnal :}

Ruspita, Leli, Keterasingan Perempuan dari Pekerjaannya: kemitraan Suami Istri dalam pengelolaan Keuangan Rumah Tangga: Jurnal Perempuan 74 untuk pencerahan dan kesehatan, Vol.17 No.3 Tahun 2012.

Kabeer, Naila, Reflectionson The Measurement ofWomen's Empowerment in Discussing Women Empowerment:Theoryand Practices. Sida Studies No3 Journal, 2001

Mudhoffi, Abdil Mughis, Teori Kekuasaan Michael Foucault: Tantangan bagi Sosiologi Politik, Jurnal Sosiologi Masyarakat, Vol.18 No.1 Januari 2013

Venny, Adriana, Mempertanyakan Kebijakan Anggaran, Jurnal Perempuan, No 46 Untuk Pencerahan dan Kesehatan sudahkah anggaran Kita, Jakarta Maret 2006

Irlang, Yuda, Kebijakan Publik dan Penganggaran Tanggap Gender, Jurnal Perempuan, No. 46 Untuk Pencerahan dan Kesehatan sudahkah anggaran Kita, Jakarta Maret 2006

\section{Dokumen :}

Undang-undang Nomor 6 Tahun 2014 tentang Desa

Permendagri Nomor 114 Tahun 2014 tentang Pedoman Pembangunan Desa Permendesa Nomor 22 tahun 2016 tentag Prioritas Penggunaan Dana Desa Tahun 2017 